Agronomic Society, held on February 9, 1911]. Dokladyi $i$ protokolyi obschih sobraniy Kievskogo agronomicheskogo obschestva-Reports and minutes of general meetings of the Kiev Agronomic Society. Kyiv: Tip. T.G. Meynandera, 1-4 [in Russian].

16. (1912). Protokol 6-go obschego sobraniya Kievskogo agronomicheskogo obschestva, sostoyavshegosya 18-go marta $1911 \mathrm{~g}$. [Protocol of the 6th general meeting of the Kiev Agronomic Society, held on March 18, 1911]. Dokladyi i protokolyi obschih sobraniy Kievskogo agronomicheskogo obschestva - Reports and minutes of general meetings of the Kiev Agronomic Society. Kyiv: Tip. T.G. Meynandera, 1-19 [in Russian].

17. Kholodnyi, M.H. (1935). Do istorii mikrobiolohii v Kyivskomu universyteti. [On the history of microbiology at the University of Kiev]. Rozvytok nauky $v$ Kyivskomu universyteti za sto rokiv - The development of science at the University of Kiev for one hundred years. Kyiv: Vyd-vo Kyiv. derzh. un-tu, 93-104 [in Ukrainian].

Одержано 18.04.2019.

УДК 94(477.53) «18/19»:633:63:061.2

\section{Якименко Микола,}

доктор історичних наук, професор кафедри гуманітарних i соціальних дисциплін

mykolaiak@ukr.net

http://orcid.org/0000-0003-3484-0764

Researcher ID: R-2371-2016

Полтавська державна аграрна академія, вул. Сковороди $1 / 3$, м. Полтава,

Україна, 03600

\section{Краснікова Оксана,}

кандидат економічних наук, доцент кафедри фінансів і кредиту

oksana.krasnikova@pdaa.edu.ua

http://orcid.org/0000-0002-1591-9613

Researcher ID: R-1874-2016

Полтавська державна аграрна академія вул. Сковороди 1/3, м. Полтава,

Україна, 03600

\section{DOI https://doi.org/10.31470/2415-3567- 2019-46-155-164}

\section{YakymenkoMykola,}

Doctor of Historical Sciences, professor of the Department Humanitarian and Social Disciplines mykolaiak@ukr.net http://orcid.org/0000-0003-3484-0764

Researcher ID: R-2371-2016

Poltava State Agrarian Academy, 1/3, Street Skovoroda, Poltava city, Ukraine, 03600

\section{Krasnikova Oksana,}

Candidate of Economic sciences, assistant professor of Department of Finance and Credit oksana.krasnikova@pdaa.edu.ua http://orcid.org/0000-0002-1591-9613 Researcher ID: R-1874-2016 Poltava State Agrarian Academy 1/3, Street Skovoroda, Poltava city, Ukraine, 03600

\title{
ВПЛИВ ТЕОРЕТИКІВ І ПРАКТИКІВ ПОЛТАВСЬКОГО СІЛЬСЬКОГОСПОДАРСЬКОГО ТОВАРИСТВА НА МОДЕРНІЗАЦІЮ ГАЛУЗІ РОСЛИННИЦТВА НА РУБЕЖI ХIX-XX ст.
}

У статті проаналізовано внесок Полтавського сільськогосподарського товариства y пропаганду агротехнічних знань не лише у масштабах полтавського регіону, але й далеко за його межами.

Очевидною заслугою членів товариства була організачія сільськогосподарських виставок, на яких не лише представники панівних класів, але й широкі маси 
непривілейованих станів, якими були на той час згідно існуючого царського законодавства селяни, козаки та міщуани, могли показувати кращі зразки жита, пшениці, кукурудзи, ячменю, проса, буряка, продукиї садівництва і т.п., сприяючи, таким чином, розповсюдженню передового досвіду у тогочасній аграрній сфері. Поряд з виставками, свою роль у модернізачії сільського господарства відігравали також систематичні публікації досягнень світової агрономічної науки на сторінках таких спеціалізованих видань, як журнали товариства та, особливо, газета-журнал «Хуторянин». Досить красномовним $\epsilon$ факт відзначення на одній із всеросійський сільськогосподарських виставок журналу «Хуторянин» золотою медаллю саме за якісні публікачї̈ з приводу тих чи інших проблем аграрного сектору економіки тогочасної держави. Окрім публікацій самого журналу його редакиія організувала ще й видання своєрідного збірника статей з аграрної тематики під назвою: «Календарь «Хуторянина»», щэо, безумовно, позитивно впливало на модернізащію галузі рослинництва не лише на Полтавщині, а й низиі інших регіонів Російської імперії.

Не викликав сумніву, щзо теоретики і практики сільськогосподарської справи суттєво сприяли вдосконаленню галузі рослинництва, адже зростання за три десятиліття активної роботи членів товариства майже удвічі урожайності таких найпоширеніших на той час культур, як жито і пшениия підтверджує даний висновок. На превеликий жаль, колоніальна політика щэодо Украӥни з боку імперського центру гальмувала прочес розповсюдження на украӥнських землях Російської імперії як освіти загалом, про щчо свідчить наявність за переписом 1897 р. у сільській місиевості Полтавщини лище 14\% грамотних людей, так і сільськогосподарської освіти зокрема. Підтвердженням такої тези $\epsilon$, наприклад, відмова Полтавському сільськогосподарському товариству у його клопотанні відкрити у Полтаві агрономічний інститут.

Ключові слова: Російська імперія, Украӥна, Полтавщиина, сільськогосподарські товариства, рослинництво.

\section{THE INFLUENCE OF THE THEORISTS AND PRACTITIONERS OF THE POLTAVA AGRICULTURAL SOCIETY ON THE MODERNIZATION OF THE CROP INDUSTRY AT THE TURN OF THE XIX-XX CENTURIES}

The article analyzes the contribution of the Poltava Agricultural Society to the propaganda of agrotechnical knowledge not only on the scale of the Poltava region, but also beyond its borders.The obvious merit of the members of the society was the organization of agricultural exhibitions, where were not only the representatives of the ruling classes, but also the large masses of underprivileged class, which at that time were peasants, Cossacks and burghers under the current royal legislation, who could show the best samples of rye, wheat, corn, millet, beetroot, horticultural products, etc., thus, contributing to the dissemination of best practices in the agricultural sector at that time. Along with the exhibitions, a great role play systematic publications of the achievements of the world agronomic science on the pages of specialized editions of the society magazines, in particular the Khutoryanin newspaper. Quite eloquent is the fact that one of the all-Russian agricultural exhibitions of Khutoryanin magazine received a gold medal for qualitative publications concerning various problems of the agrarian sector of the economy of the state at that time. In addition to the publications of the magazine itself, its editors also organized the collection of articles on agricultural topics entitled: "The Khutoryanin calendar», which has certainly had a positive effect on the modernization of the plant growing sector, but not only in Poltava and also in several other regions of the Russian Empire. There is no doubt that agricultural theorists and practitioners have significantly contributed the improvement of the crop industry, because the growth of the active work of society members doubled for the three decades of the most widespread crops of the time, such as rye and wheat, which confirms this conclusion.Unfortunately, the colonial policy of Ukraine by the imperial 
center hindered the process of dissemination of education on the Ukrainian lands of the Russian Empire as a whole, as evidenced by the census of 1897 in the rural areas of Poltava region there was only $14 \%$ of the competent people and agricultural education in particular. Such thesis is supported by the refusal of the Poltava Agricultural Society in its request to open an agronomic institute in Poltava.

Keywords: Russian Empire, Ukraine, Poltava region, agricultural societies, crop production.

Сучасний аграрно-промисловий комплекс України знаходиться на завершальній стадії переходу від командно-адміністративних методів господарювання до ринкових, тобто тих, на основі яких функціонує сьогодні економіка країн Свропейського Союзу.

Використовуючи досвід передових країн світу для створення в Україні ефективного сільськогосподарського виробництва 3 метою його успішної конкуренції на ринку товарів і послуг, не слід, однак, забувати і власний історичний досвід здійснення модернізації усіх галузей народного господарства, який мав місце у нашій країні після скасування у 1861 р. кріпосного права.

Фахівцям економічної історії відомі три типи модернізації: піонерська, органічна i наздоганяюча. Як і у щойно згаданий період, так і в сучасних українських реаліях, чітко прослідковується саме наздоганяючий тип модернізації, що суттєво актуалізує, наприклад, вивчення такого центру аграрної модернізації кінця XIX - початку XX ст. як Полтавське сільськогосподарське товариство.

Полтавське сільськогосподарське товариство було об'єктом пильної уваги вже у перші десятиліття 3 початку його активної діяльності, підтвердженням чого стали публікації В. Тихомирова [22], М. Сосновського та С. Велецького [20].

У радянський період вітчизняної історії через відомі причини така проблематика як історія сільськогосподарських товариств, вважалась неактуальною, а тому практично не вивчалась. Однак, після краху тоталітарного режиму у 1991 р. і початку ринкових реформ, увага до їх діяльності помітно зросла, про що свідчать публікації А.О. Пантелеймоненка [9], В.А. Вергунова [1], В.М. Самородова і С.Л. Кигим [17] та низки інших дослідників [6; 23]. Проте, у зазначених публікаціях має місце загальна характеристика діяльності цієї громадської організації кооперативного типу. Метою нашого дослідження є аналіз того впливу, який здійснили теоретики і практики сільського господарства на модернізацію рослинництва.

На рубежі XIX-XX ст. Полтавська губернія належала до числа найбільших як за

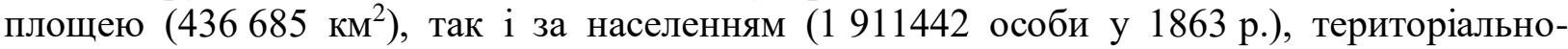
адміністративних одиниць центрально-чорноземного регіону імперії [21, с. 4-5]. Станом на 1861 р. мешканці Полтавщини утримували 3470 тис. голів свійських тварин, з яких 180 тис. коней, 703 тис. - велика рогата худоба, 2050 тис. - овець і 537 тис. голів свиней [18, c. 195]. За кількістю тварин дана губернія посідала перше місце серед усіх аналогічних регіонів підросійської України. Посівна площа, згідно даних статистики 1870-1874 pp., сягала 2435 тис. десятин при урожайності жита 29 пудів 3 дес., а пшениці - 21 пуд [18, c. 168,170$]$.

Пояснюючи причини організаційного оформлення у 1865 p. Полтавського сільськогосподарського товариства, знаний в країні агроном О. Іллічевський у 1915 p. писав, що скасування кріпосного права поставило перед сільським господарством «стільки великих і нових проблем, що об'єднання їх стало особливо необхідним» [3, c. 873]. Так, власне, 21 травня 1865 p. і виникло Полтавське сільськогосподарське товариство, яке відразу ж почало активно обговорювати такі актуальні на той час питання, як «покращення обробітку грунту, удобрення ланів, посіви люцерни й еспарцету, вдосконалення знарядь праці, збереження лісів, правильної оцінки земель при оподаткуванні, організації доступного кредиту..., тощо» [3, с. 875]. Як відзначала у 
1913 р. редакція журналу «Хуторянин», діяльність сільськогосподарських товариств Полтавщини мала два основні аспекти: А) просвітницький і Б) практичний [10, с. 140].

Перший із щойно згаданих аспектів передбачав публікацією відповідної науковопопулярної інформації в газетах, журналах, на сторінках брошур, книг та різного роду статистичних збірників, довідників, календарів і т.п. У 60-х pp. XIX ст. Полтавське товариство знайомило громадськість 3 досягненнями світової агрономічної науки за допомогою спеціального сільськогосподарського збірника, який у 1867 р. став редагувати секретар товариства чех Ф.Н. Гейдук. Протягом зазначеного року побачило світ шість випусків такого збірника [19]. Наступним друкованим органом товариства стали «Журнали засідань Полтавського сільськогосподарського товариства», перший випуск якого було віддруковано у 1878 р. Усі видання «журналів», починаючи з цього року і по 1910 р. включно, у 2015 р. з ініціативи директора ННСГБ НААН України В.А. Вергунова було перевидано у п'яти окремих випусках [12-16]. Членів товариства цікавили найрізноманітніші сюжети, пов'язані 3 вирощуванням як зернових, так і технічних культур. Лише у 80-х pp. XIX ст. на засіданнях Полтавського сільськогосподарського товариства були обговорені доповіді А.Н. Волжина про культуру цукрового буряка; А.П. Величківського про причини поганого урожаю кукурудзи; Г. Гаркушевського про досвід вирощування сорго у Катеринославській губернії; К.К. Дятлова про культуру вирощування кукурудзи; професора Харківського університету А.Е. Зайкевича про технологію посівів кукурудзи; П.А. Заборинського про досвід вирощування кукурудзи в умовах лісостепу та про урожай зернових культур в Чорбівській та Миколаївській економіях в період з 1857 по 1884 роки; Г.М. Зеленського про технологію силосування сухих рослин кукурудзи; А.А. Ізмаїльського про значення вирощування цукрового сорго в умовах степу і лісостепу; А.А. Колесова про розведення кукурудзи на зерно; М.В. Кибальчича про досвід вирощування великого пляшкоподібного кормового буряка та про досвід силосування бур'янів; редактора «Земледельческой газеты» В.А. Кудашева про безприбутковість посівів кукурудзи; І.К. Коляновського про шкоду гессенської мухи на озимих посівах; I. Мусіна-Пушкіна про розведення еспарцету; А.I. Ната про зберігання перегною і деякі особливості посівів озимої пшениці; Н. Родніна про раннє янтарне сорго, його культивування та техніки переробки; В. Родзянка про вирощування спаржі та догляд за нею; два повідомлення Р.П. Трипільського про культивування і силосування кукурудзи (у 1882 та 1883 роках); секретаря товариства В.А. Тихомирова про вартість вирощування жита і пшениці; про вплив глибокої та мілкої оранки при вирощуванні кукурудзи і картоплі; про удобрення і обробіток грунту; звіт директора Полтавського дослідного поля про В.П. Черепахіна про результати роботи у 1885 р. та 1886 р. про економічні наслідки глибокої оранки чорноземних грунтів згаданого автора [22, с. 45-47].

Починаючи з 1896 р., найпоширенішим способом пропаганди агротехнічних знань став щотижневик «Хуторянин» - друкований орган Полтавського сільськогосподарського товариства. Ще 26 лютого 1884 р. на засіданні товариства було ухвалене рішення просити у губернатора дозволу на друкування сільськогосподарського листка, однак тривалий час справа не вирішувалась як з фінансових причин (потрібно було знайти 3000 рублів), так і 3 суто політичних, адже царська влада дуже неохоче давала дозволи на заснування у регіонах імперії друкованих засобів інформації [13, с. 101]. Врешті-решт на початку 1896 р. відповідні кошти були знайдені, як i рішення про видання щотижневої сільськогосподарської газети «без попередньої цензури» під редакцією гвардії поручика Д.К. Квітки [16, с. 166]. У 1899 р. серед підписників «Хуторянина» редакція газети, який за своєю формою став, фактично, журналом, провела анкетування з метою з'ясування соціального складу та професійних занять своїх читачів. Виявилося, що 63,5\% читачів належали до складу так званих сільських станів; 18,7\% - дворян і різночинців; 4,3\% купців і міщан; 8,0\% - духовенства; 2,6\% - сільських учителів та осіб без певного звання; $0,9 \%$ - земські та державні установи; $2,0 \%$ - звання невідомі. На запитання щодо того, чи давали підписники читати газету іншим особам, були отримані такі відповіді: дають 
читати сусідам - 57,5\%; давали одній особі - 7,1\%; давали службовцям місцевої економії - 3,2\%; давали до бібліотеки - 1,2\%; не давали нікому - 31,0\%. Важливим, 3 точки зору перспектив розвитку сільського господарства, було переважання у складі читачів молодих людей $[7$, с. $3,5,7]$.

Станом на 1904 р. тираж газети зріс до 3000 примірників, які розсилались своїм підписникам, окрім Полтавської, ще й у Чернігівську, Катеринославську, Харківську, Херсонську, Київську, Курську, Ставропільську, Таврійську, Воронезьку, Саратовську, Самарську та низка інших регіонів імперії [7, с. 235]. Станом на 1913 р. 7857 підписників «Хуторянина» вже мешкали майже в усіх регіонах імперії, а 13 з них мали навіть закордонні адреси $[11$, с. 27]. Про якість цього видання говорить факт відзначення «Хуторянина» на одній з виставок 1910 р. золотою медаллю.

У зв'язку 3 актуалізацією аграрного питання у рокистолипінських реформ Полтавське сільськогосподарське товариство разом з губернським земством організувало видання ще одного органу розповсюдження агротехнічних знань під назвою: «Календарь «Хуторянина»», шість випусків якого побачили світ у 1909-1916 рр. Окрім власних видань, Полтавське сільськогосподарське товариство мало у своєму розпорядженні бібліотеку, де усі бажаючі могли ознайомитися зі змістом таких журналів і газет, як: «Труды императорского вольного экономического общества», «Сельское хозяйство и лесоводство», «Земледельческая газета», «Жатва», «Известия Петровской земледельческой и лесной академии», «Известия императорского Московского общества сельского хозяйства», «Вестник Российского общества садоводства», журналисільськогосподарських товариств: Кобеляцького, Смоленського, Мінського, Київського і Харківського, видання Полтавської губернської земської управи та низка інших [12, с. 251].

Зважаючи на те, що близько 14\% сільських мешканців не знали грамоти [15, с. 209], Полтавське товариство широко практикувало такі методи пропаганди агротехнічних знань, як губернські, повітові і навіть сільськівиставки. Так, лише у 80-х pp. XIX ст. товариство організувало шість губернських виставок $(1879,1883,1886$ pp. у Полтаві; 1880 i 1884 pp. у Ромнах; 1881 р. у Кременчуці). Окрім цього, у містах Полтавщини протягом вказаного періоду було проведено 15 регіональних виставок [22, с. 42]. Так, на губернську сільськогосподарську виставку, відкриту 9 вересня 1893 р., було представлено землеробські знаряддя праці, продукція рослинництва i тваринництва, садівництва, городництва та лісництва, кустарні вироби, продукція переробної промисловості та деякі інші експонати. Протягом 24 днів виставку відвідало 21569 осіб, які внесли до їі каси 2859 руб. 20 коп., тоді як на попередніх аналогічних виставках прибуток ледве сягав 1000 руб. [8, с. 16].За результатами конкурсу відповідних експонатів переможці отримували нагороди: золоті, срібні або бронзові медалі, а також похвальні грамоти. У 1899 р., наприклад, на Роменській сільськогосподарській виставці золоту медаль отримав Дукельський Г.П. за «відмінну колекцію насіння та результати господарства за останні чотири роки» [2, с. 21].

Ще одним способом пропаганди новітніх досягнень агрономічної науки була діяльність Полтавського дослідного поля, ідея заснування якого правління товариства визнало доцільним ще наприкінці 1879 р. [12, с. 76]. Але розпочати практичну роботу цієї установи вдалося лише 31884 р. [5, с. 5]. Про значення цієї установи у справі розповсюдження новітніх агротехнічних знань говорить такий факт, як відзначення п'яти його активних діячів (С.Ф. Третяков, Б.М. Прянишников, Б.М. Рождественский, К.Г. Маньківський, С.Л. Франкфурт) золотою медаллю «За труды по опытному делу» [17, c. 34].

Значну активність Полтавське сільськогосподарське товариство проявляло і у справі розповсюдження агротехнічних знань через сільськогосподарські школи, спеціалізовані курси та екскурсії. Вперше ідея необхідності заснування на Полтавщині сільськогосподарських шкіл активно обговорювалась на засіданні товариства 20 липня 
1881 р. Одним 3 активних прихильників таких шкіл став член товариства професор А.Е. Зайкевич [12, с. 151]. У листопаді того ж року ідею сільськогосподарських шкіл підтримав член правління Д.К. Квітка [13, с. 174]. Після кількарічного обговорення ідеї сільськогосподарських шкіл у березні 1884 p. Полтавське товариство вирішило приступити до практичної реалізації наміченого плану заснування у Полтавській губернії училища садівництва і городництва. У відповідному клопотанні на адресу Міністерства державних маєтностей товариство пропонувало відкрити такий навчальний заклад у Лубнах або у Полтаві [13, с. 107]. У червні 1894 р. член товариства Н.Г. КулябкоКорецький на засіданні товариства вніс пропозицію підтримати ідею заснування у Полтаві не школи, а «вищого агрономічного навчального закладу» [15, с. 85]. На думку цього автора існування в усій імперії лише трьох вищих агрономічних навчальних закладів $\epsilon$ «для Росії недостатнім». Якщо і відкривати ще один подібний навчальний заклад, то кращого місця, ніж Полтава, годі й шукати. Ї̈̈ переваги - «сприятливий клімат, відносна дешевизна життя і зручне залізничне сполучення...» [24, с. 12].

Однак імперська влада не бажала мати на території національних окраїн широкої сітки навчальних закладів взагалі і вищих у вигляді інститутів чи університетів, зокрема. Не зайвим буде у цьому зв'язку згадати відповідь імператриці Катерини II на клопотання гетьмана України Кирила Розумовського про відкриття у тодішній столиці Батурині відповідного навчального закладу: «Колониальным народам университеты иметь запрещается» [5].

У будь-якому випадку фактом залишається категорична відмова уряду дати позитивну відповідь полтавцям щодо ідеї заснування у краї 3 тримільйонним малоосвіченим населенням вищої агрономічної інституції. На практиці ж царська влада обмежилась лише дозволом на відкриття в губернії наприкінці XIX ст. кількох сільськогосподарських шкіл (Андріївська, Жабківська, Золотоніська, Костянтиноградська та Лубенська).

Згідно 3 розпорядженням міністра землеробства і державних маєтностей було схвалено Статут Полтавської найнижчої (підкреслено там - Авт.) школи садівництва i городництва 2-го розряду. Саме дана школа 3 трирічним терміном навчання стала основою для формування у 20 -х pp. XX ст. на її базі сільськогосподарського технікуму, а у 1929 р. й інституту, що у 2000 рр. став теперішньою аграрною академією.

Намагаючись охопити якомога ширше коло селянства сільськогосподарською освітою 16 грудня 1900 p. Полтавське сільськогосподарське товариство навіть обговорювало питання організації за прикладом Німеччини так званих «зимових шкіл по сільському господарству» [15, с. 323].

На практиці ж у роки столипінських реформ вдалося організувати проведення в окремих повітах кількатижневих сільськогосподарських курсів, якими керували місцеві агрономи. Для узгодження просвітницької роботи на теренах Полтавської губернії такий активний член правління товариства, як Віктор Василенко на початку $1899 \mathrm{p}$. запропонував заснувати у краї щось на кшталт агрономічної організації [15, с. 234]. Ідея була підтримана і вже наступного року (15.12.1900 р.) було вирішено провести у приміщенні товариства відповідну агрономічну нараду, у якій взяло участь 45 осіб, включаючи керівників усіх п'яти сільськогосподарських шкіл [15, с. 295]. У наступних роках періодично стали проводитись не лише агрономічні наради, але й конференції представників, якщо не усіх сільськогосподарських товариств, то, принаймні, значної їх частини.

Як би там не було, але навряд чи хто з дослідників будезаперечувати позитивний вплив Полтавського сільськогосподарського товариства загалом та найактивніших його членів, зокрема, на підвищення ефективності сільського господарства Полтавщини. Так, наприклад, у 80-х pp. XIX ст., коли Полтавське товариство сільського господарства тільки-но розпочинало свою роботу, а у повітах і селах таких кооперативних об'єднань взагалі ще не було, урожаї основних зернових культур за три десятиліття зросли більш як 
на половину, що добре ілюструє таблиця 1.

Порівнюючи показники 80-х pp. ХІХ ст. 3 відповідними даними 10-х pp. XX ст., констатуємо наступне: за три десятиліття площа посівів зросла на 113,3\%; збір зернових на 194,5\%, а урожай з десятини угідь - на 174,3\%. Як бачимо, прогрес очевидний, і далеко не останню роль у цьому відіграло Полтавське сільськогосподарське товариство загалом i його почесні і дійсні члени зокрема.

Таблиця 1

Полтавська губернія у 1883-1915 роках*

\begin{tabular}{|c|c|c|c|c|c|c|c|}
\hline Роки & $\begin{array}{c}\text { Площа } \\
\text { посіву в } \\
\text { десятих }\end{array}$ & $\begin{array}{c}\text { 3бір } \\
\text { зернових } \\
\text { в } \\
\text { тис.пудів }\end{array}$ & $\begin{array}{c}\text { Урожай } з \\
\text { десятини } \\
\text { в пудах }\end{array}$ & Роки & $\begin{array}{c}\text { Площа } \\
\text { посіву } \\
\text { в дес. }\end{array}$ & $\begin{array}{c}\text { Збір } \\
\text { зернових } \\
\text { в } \\
\text { тис.пудів }\end{array}$ & $\begin{array}{c}\text { Урожай } 3 \\
\text { десятини } \\
\text { в пудах }\end{array}$ \\
\hline 1883 & $1,819,1$ & 61034,9 & 34,1 & 1911 & 2009,0 & 130638,5 & 65,0 \\
\hline 1884 & 1824,9 & 67910,9 & 37,2 & 1912 & 1984,7 & 131670,4 & 66,3 \\
\hline 1885 & 1829,2 & 72903,6 & 39,8 & 1913 & 2131,5 & 168820,2 & 79,2 \\
\hline 1886 & 1817,2 & 44808,4 & 24,6 & 1914 & 2108,0 & 136552,8 & 64,8 \\
\hline 1887 & 1812,6 & 108525,5 & 59,9 & 1915 & 2080,2 & 133667,7 & 64,3 \\
\hline $\begin{array}{c}\text { Середнє } \\
\text { число }\end{array}$ & 1820,6 & 71036,7 & 39,2 & $\begin{array}{c}\text { Середнє } \\
\text { число }\end{array}$ & 2062,7 & 140269,9 & 68,0 \\
\hline Джерело. & \multicolumn{7}{|c|}{ Влияние неурожаев на народное хозяйство России / Под ред. } \\
\hline
\end{tabular}

Відзначення у 2015 р. 150-річчя Полтавського сільськогосподарського товариства зайвий раз засвідчило ту позитивну з економічної точки зору роль, яку відіграла ця громадська організація у модернізації сільськогосподарського виробництва на теренах України у другій половині XIX і на початку XX ст. Не шкодуючи свого вільного часу, адже інколи засідання товариства завершувалися лише опівночі, його члени крок за кроком вирішували (у міру своїх можливостей і повноважень) цілу низку актуальних проблем рослинництва - від технології обробітку грунтів до пошуку шляхів підвищення урожайності тих культур, які культивувалися на Полтавщині. 3 точки зору перспектив подальшого вивчення проблеми певний інтерес становлять питання, пов'язані $з$ аналізом тієї ролі, яку відігравали товариства у розробці законодавчих актів щодо забезпечення сільськогосподарських товаровиробників кредитними ресурсами.

\section{ДЖЕРЕЛА ТА ЛІТЕРАТУРА}

1. Вергунов В.А. Полтавському товариству сільського господарства150 років. Київ: ТОВ «Нілан-ЛТД», 2015. 52 с.

2. Двадцатипятилетие Полтавской опытной станции (1884-1909г.). Вып. 2-й. Историч. Обзоры. Полтава: Электрич. типо-литогр. И.Л. Фришберга, 1916. 87 с.

3. Илличевский О. Полувековая деятельность Полтавского общества сельского хозяйства // Хуторянин. 1915. №42. С. 873-875

4. Имшенецкий Я.К. «Хуторянин» и его читатели. Доклад, читаный в годичном заседании Полтавского общества сельского хозяйства 23 ноября 1900 года. Полтава: Типолитогр. Л.Т. Фришберга, 1981. 56 с.

5. Кулябко-Корецкий Н.Г. Об устройстве в сельскохозяйственного учебного заведения // Журналы заседания Полтавского с.-х. общества. За 1894 г. Полтава, 1895. №3-4. С.1-15.

6. Лисенко М.С. Полтавське товариство сільського господарства: історія і досвід (до 150 річниці) // Сумська старовина. 2015. №XLVII. С. 41-52. 
7. Отчет Полтавского общества за 1913 год. Полтава: Электрич. тип. Д.Н. Подземского, 1916. 52 с.

8. Отчет Роменской сельскохозяйственной и кустарно-промышленной выставки 1899 года. Ромны: Тип. Бр. Э.и Н. Дельберг, 1901. 130 с.

9. Пантелеймоненко А.О. Сільськогосподарські товариства України: зародження, основні напрямки діяльності і значення (друга половина XIX - початок XX ст.): автореф. дис. канд. екон. наук: 08.01.04 - Економічна історія. Київ, 1994. 20 с.

10. Первый сборник сельскохозяйственных статей (календарь «Хуторянин» на 1909 год). Полтава: Б.и., 1913. 183 с.

11. Полтавская губернская сельскохозяйственная выставка 1893 года. Отчет распорядительного комитета выставки. Составил член Полтавского сельскохозяйственного общества С.Н. Велецький. Полтава: Типо-литогр. Л. Фришберга, $1895.247 \mathrm{c}$.

12. Полтавське товариство сільського господарства (журнали засідань 35 серпня 1878 р. по 29 травня 1883 р.) / Уклад. В.А. Вергунов, Н.Ф. Гриценко, К.О. Черноколова, Н.М. Опара; ННСГБ НААН; підзаг. ред. В.А. Вергунова. Вінниця: ФОП Корзун Д.Ю., 2015. Вип.1. 356 с.

13. Полтавське товариство сільського господарства (журнали засідань 315 липня 1883 р. по 20 грудня 1887 р. / Уклад. В.А. Вергунов, Н.Ф. Гриценко, К.О. Черноколова, Н.М. Опара; ННСГБ НААН; під заг. ред. В.А. Вергунова. Вінниця: ФОП Корзун Д.Ю., 2015. Вип. 2. Ч. 1.492 с.

14. Полтавське товариство сільського господарства (журнали засідань 324 січня 1888 р. по 18 серпня 1893 р.) / Уклад. В.А. Вергунов, Н.Ф. Гриценко, К.О. Черноколова, Н.М. Опара; ННСГБ НААН; під заг. ред. В.А. Вергунова. Вінниця: ФОП Корзун Д.Ю., 2015. Вип. 2. Ч. 2. 464 с.

15. Полтавське товариство сільського господарства (Журнали засідань з 3 листопада 1893 р. по 7 березня 1901 р.) / Уклад. В.А. Вергунов, Н.Ф. Гриценко, Н.М. Опара; ННСГБ НААН; під заг. ред. В.А. Вергунова. Вінниця: ФОП Корзун Д.Ю., 2015. Вип. 3. Ч. 1. 418 с.

16. Полтавське товариство сільського господарства (Журнали засідань з 4 березня 1901 р. по 22 грудня 1910 р.) / Уклад. В.А. Вергунов, Н.Ф. Гриценко, Н.М. Опара; ННСГБ НААН; під заг. ред. В.А. Вергунова. Вінниця: ФОП Корзун Д.Ю., 2015. Вип. 3.Ч. 2. 418 с.

17. Самородов В.М. Полтавське сільськогосподарське товариство (1865-1929 рр.): історія, звитяги, першопостаті. Полтава: Дивосвіт, 2015. 160 с.

18. Сельское хозяйство Украины / Под ред. М.Б. Гуревича и В.М. Соловейчика. Харьков: Издат. Отдел Н.К.З., 1923. 232 с.

19. Сельскохозяйственный сборник. Земледельческий журнал, издаваемый Полтавским сельскохозяйственным обществом / Под ред. Д. Гейдука. Полтава: Б.и., 1867. Вып. 1. 21 с.; Вып.2. 49 с.; Вып.3. 25 с.; Вып. 4-5. 64 с.; Вып. 6.26 с.+113 с.

20. Сосновский М. Полтавское сельскохозяйственное общество. 1865-1895 гг. Полтава: Типо-литогр. Л. Фришберга, 1897. 11 с.

21. Статистический временник Российской империи. Санкт-Петербург: Изд-е ЦСК МВД, 1866. 159c.

22. Тихомиров В.А. Историческая записка о деятельности Полтавского сельскохозяйственного общества с 1865 г. по 1887 г. Полтава: Тип. наследн. Н. Пигуренко, 1887. 183 с.

23. Якименко М.А. Полтавське сільськогосподарське товариство: організаційна структура та основні напрямки діяльності (1865-1917 роки) // Історична пам’ять. 2009. №1 . C. 46-53.

\section{REFERENCES}

1. Verhunov, V.A. (2015). Poltavskomu tovarystvu silskoho hospodarstva150 rokiv [Poltava Agricultural Society 150 years]. Kyiv: TOV «Nilan-LTD» [in Ukrainian]. 
2. (1916). Dvadtsatipyatiletiye Poltavskoy opytnoy stantsii (1884-1909 g.) [Twenty-fifth anniversary of the Poltava Experimental Station (1884-1909)]. Istorich. Obzory - Historian Reviews, 2. Poltava: Elektrich. tipo-litogr. I.L. Frishberga [in Russian].

3. Illichevskiy, O. (1915). Poluvekovaya deyatelnost Poltavskogo obshchestva selskogo khozyaystva [Semi-Century Activity of the Poltava Society of Agriculture]. Khutoryanin Khutoryanin, 42, 873-875 [in Russian].

4. Imshenetskiy, Ya.K. (1981). «Khutoryanin» i yego chitateli. Doklad, chitanyy v godichnom zasedanii Poltavskogo obshchestva selskogo khozyaystva 23 noyabrya 1900 goda ["Farmers» and his readers. Report read at the Annual Meeting of the Poltava Society of Agriculture on November 23, 1900]. Poltava: Tipo-litogr. L.T. Frishberga [in Russian].

5. Kulyabko-Koretskiy, N.G. (1895). Ob ustroystve v g. Poltave vysshego selskokhozyaystvennogo uchebnogo zavedeniya [On the structure of the higher agricultural educational institution in Poltava]. Zhurnaly zasedaniya Poltavskogo s. -kh. obshchestva. Za 1894 g. - Journal of the meeting of the Poltava agricultural university. society. For 1894, 3-4, 1-15 [in Russian].

6. Lysenko, M.S. (2015). Poltavske tovarystvo silskoho hospodarstva: istoriia i dosvid (do 150 richnytsi) [Poltava Society of Agriculture: History and Experience (to the 150th Anniversary)]. Sumska starovyna - Sumy Antiquity, XLVII, 41-52 [in Ukrainian].

7. (1916). Otchet Poltavskogo obshchestva za 1913 god [Report of the Poltava society for 1913]. Poltava: Elektrich. tip. D.N. Podzemskogo [in Russian].

8. (1901). Otchet Romenskoy selskokhozyaystvennoy $i$ kustarno-promyshlennoy vystavki 1899 goda [Report of the Romny Agricultural and Handicraft Industrial Exhibition of 1899]. Romny: Tip. Br. E.i N. Delberg [in Russian].

9. Panteleimonenko, A.O. (1994). Silskohospodarski tovarystva Ukrainy: zarodzhennia, osnovni napriamky diialnosti i znachennia (druha polovyna XIX - pochatok XX st.): avtoref. dys. kand. ekon. nauk: 08.01.04 - Ekonomichna istoriia [Agricultural societies of Ukraine: origins, main activities and values (second half of XIX - beginning of XX century): author. diss. Cand. econom. Sciences: 08.01.04 - Economic history]. Kyiv [in Ukrainian].

10. (1913). Pervyy sbornik selskokhozyaystvennykh statey (kalendar «Khutoryanin» na 1909 god) [The first collection of agricultural articles (calendar «Farmer» for 1909)]. Poltava: B.i. [in Russian].

11. (1895). Poltavskaya gubernskaya selskokhozyaystvennaya vystavka 1893 goda. Otchet rasporyaditelnogo komiteta vystavki. Sostavil chlen Poltavskogo selskokhozyaystvennogo obshchestva S.N. Veletskiy [Poltava provincial agricultural exhibition of 1893. Report of the steering committee of the exhibition. Compiled by a member of the Poltava Agricultural Society S.N. Veletsky]. Poltava: Tipo-litogr. L. Frishberga [in Russian].

12. Verhunova, V.A. (Ed.) (2015). Poltavske tovarystvo silskoho hospodarstva (zhurnaly zasidan z 5 serpnia 1878 r. po 29 travnia 1883 r.) [Poltava Agricultural Society (logs of meetings from August 5, 1878 to May 29, 1883)], 1 [in Ukrainian].

13. Verhunova, V.A. (Ed.) (2015). Poltavske tovarystvo silskoho hospodarstva (zhurnaly zasidan z 15 lypnia 1883 r. po 20 hrudnia 1887 r. [Poltava Society of Agriculture (logs of meetings from July 15, 1883 to December 20, 1887)], 2, 1 [in Ukrainian].

14. Verhunova, V.A. (Ed.) (2015). Poltavske tovarystvo silskoho hospodarstva (zhurnaly zasidan z 24 sichnia 1888 r. po 18 serpnia 1893 r.) [Poltava Society of Agriculture (logs of meetings from January 24, 1888 to August 18, 1893)], 2, 2 [in Ukrainian].

15. Verhunova, V.A. (Ed.) (2015). Poltavske tovarystvo silskoho hospodarstva (Zhurnaly zasidan z 3 lystopada 1893 r. po 7 bereznia 1901 r.) [Poltava Society of Agriculture (Meeting logs from November 3, 1893 to March 7, 1901)], 3, 1 [in Ukrainian]. 
16. Verhunova, V.A. (Ed.) (2015). Poltavske tovarystvo silskoho hospodarstva (Zhurnaly zasidan z 4 bereznia 1901 r. po 22 hrudnia 1910 r.) [Poltava Society of Agriculture (Meeting logs from March 4, 1901 to December 22, 1910)], 3, 2 [in Ukrainian].

17. Samorodov, V.M. (2015). Poltavske silskohospodarske tovarystvo (1865-1929 rr.): istoriia, zvytiahy, pershopostati [Poltava Agricultural Society (1865-1929): history, customs, pervades]. Poltava: Dyvosvit [in Ukrainian].

18. Gurevich, M. (Ed.) (1923). Selskoye khozyaystvo Ukrainy [Agriculture of Ukraine]. Kharkov: Izdat. Otdel N.K.Z [in Russian].

19. Geyduka, D. (Ed.) (1867). Selskokhozyaystvennyy sbornik. Zemledelcheskiy zhurnal, izdavayemyy Poltavskim selskokhozyaystvennym obshchestvom [Agricultural collection. Agricultural journal published by the Poltava Agricultural Society], 1, 2, 3, 4-5, 6 [in Russian].

20. Sosnovskiy, M. (1897). Poltavskoye selskokhozyaystvennoye obshchestvo. 1865-1895 gg. [Poltava Agricultural Society. 1865-1895]. Poltava: Tipo-litogr. L. Frishberga [in Russian].

21. (1866). Statisticheskiy vremennik Rossiyskoy imperii [Statistical temporary of the Russian Empire]. Sankt-Peterburg: Izd-ye TsSK MVD [in Russian].

22. Tikhomirov, V.A. (1887). Istoricheskaya zapiska o deyatelnosti Poltavskogo selskokhozyaystvennogo obshchestva s $1865 \mathrm{~g}$. po $1887 \mathrm{~g}$. [istorical note on the activities of the Poltava Agricultural Society from 1865 to 1887]. Poltava: Tip. nasledn. N. Pigurenko [in Russian].

23. Yakymenko, M.A. (2009). Poltavske silskohospodarske tovarystvo: orhanizatsiina struktura ta osnovni napriamky diialnosti (1865-1917 roky) [Poltava Agricultural Society: Organizational Structure and Main Activities (1865-1917)]. Istorychna pam'iat - Historical Memory, 1, 46-53 [in Ukrainian].

Одержано 26.04.2019.

УДК 94:271.2-384](477.83) «1922/1944»(092)

\section{Березанська Ірина,}

кандидат історичних наук, викладач кафедри історії та культури України berezanska.im@gmail.com

https://orcid.org/0000-0002-7182-5750

Державний вищий навчальний заклад «Переяслав-Хмельницький державний педагогічний університет імені Григорія Сковороди», вул. Сухомлинського, 30, м. Переяслав-Хмельницький, Київська обл. Україна, 08401
DOI https://doi.org/10.31470/2415-35672019-46-164-173

\section{Berezanska Iryna,}

Candidate of Historical Sciences, a lecturer of Department of History and Culture of Ukraine berezanska.im@gmail.com

https://orcid.org/0000-0002-7182-5750

Pereiaslav-Khmelnytskyi Hryhorii Skovoroda State Pedagogical University,

30, Sukhomlynsky Str.,

Pereiaslav-Khmelnytskyi, Kyiv region,

\title{
ДУШПАСТИРСЬКА ТА ГРОМАДСЬКА ДІЯЛЬНІСТЬ О. ОМЕЛЯНА КОВЧА У МІСТІ ПЕРЕМИШЛЯНИ (1922-1944 pp.)
}

\author{
Служіння \\ о. Омеляна людям, незалежно \\ від віку, \\ національності, релігійних переконань свідчить про його
}

